\title{
Strangers in Digiland
}

\author{
Rozália Klára Bakó, Gyöngyvér Erika Tókés \\ Sapientia Hungarian University of Transylvania, Romania \\ socio@uni.sapientia.ro
}

\begin{abstract}
With the growing importance of digital practices in young children's everyday routines, parents and educators often face frustration and confusion. They find it difficult to guide children when it comes to playing and learning online. This research note proposes an insight into parents' and educators' concerns related to children's and their own digital literacy, based on two exploratory qualitative inquiries carried out from March 2015 to August 2017 among 30 children aged 4 to 8 from Romania, their parents and educators. The research project Digital and Multimodal Practices of Young Children from Romania (2015-2016) and its continuation The Role of Digital Competence in the Everyday Lives of Children Aged 4-8 (2017-2018, ongoing) are part of a broader effort within the Europe-wide COST network IS1410 - The Digital and Multimodal Practices of Young Children (2014-2018). Parents and educators are disconnected from young children's universe, our research has found. The factors enabling adults' access to "Digiland" and ways of coping with the steep learning curve of digital literacy are explored through parents' and teachers' narratives, guided observation of children's digital practices, and expert testimonies.
\end{abstract}

Keywords: parents, teachers, digital literacy, Romania

\section{Introduction}

With the Internet embedded in individual and community life (Wellman et al., 2003), digital literacy becomes a critical factor in children and youth empowerment (Kahne-Middaugh, 2012). When it comes to digital empowerment, interactivity enables the shift from a mechanic to an organic approach towards research and policy making: from paternalistic to participatory methods, from resourcedriven to needs-driven development strategies (Mäkinen, 2006: 385). As digital citizenship is increasingly the new educational focus, it is critical to develop both respectful online behaviour and to practice online civic engagement (JonesMitchell, 2016: 2064). Are children and youth prepared for the opportunities and 
challenges of a participatory culture? Are parents and educators ready to keep up with digital natives? Is the digital world, or "Digiland" an important part of their lives?

\section{Digital Literacy and Social Inclusion}

The ubiquitous presence of information and communication technologies in general and of smart devices in particular has reshaped the way we interact. Children become more and more part of this new "online interaction order" (Marsh, 2011: 101). Meanwhile, many parents and educators encounter difficulties when it comes to understanding the connected generations' world, in particular the adults left behind. The "digital underclass" of vulnerable groups (Helsper-Reisdorf, 2016: 2) is marked by age (the elderly), education (high school and below), and disability. While digital empowerment and social inclusion are usually approached separately, recent inquiries suggest the need for exploring good practices of treating them together. For example, educators may catalyse families' digital literacy by strengthening ties between school and family (Arrow-Finch, 2013; Blau-Hameiri, 2016).

The urge to digitally empower Romanian young children in order to prepare them to take advantage of digital technologies for a lifetime cannot be underestimated. Digital empowerment assumes both the transfer of knowledge, competence, and understanding of the digital environments and the supporting change of the socio-cultural context where children establish digital practices. The use of digital technologies by Romanian children at home and in educational settings, the level of their digital competence was studied through guided observations, informal discussions with children, and visual methods: a content analysis of their thematic drawings (Bakó, 2014; Tókés, 2016). The most used digital device of children aged 4 to 8 years old was the tablet, accessible to most families, although in various levels of technical quality. However, the most popular media channel of young children was still television, used primarily for watching cartoons. A guided observation of 18 kindergarten and 7 school children's use of highend tablets ${ }^{1}$ resulted in clear differences when it comes to digital competences, as shown in the table below. Age is an important factor, along with family background (Bakó, 2016).

The empowering role of the family and education in the formation of efficient digital practices and development of digital competence of Romanian children is an important conclusion of the Digital and Multimodal Practices of Young Children from Romania research project (2015-2016) funded by the Institute for Scientific Research of Sapientia University, Cluj-Napoca, Romania. We found

1 Samsung Galaxy Note 10.1', 2014 edition, provided by the researchers. 
that the use of digital technologies among Romanian children was interrelated with the digital practices of the family and especially the mother, or rather their digital practices responded to needs of entertainment and spending spare time. Their favourite games and applications were Minecraft, Angry Birds, Grand Theft Auto, Crossy Road, Temple Run, Zig Zag, and Minion Rush. We also observed that preschool education misses the conscious use of digital technologies. An active intervention is necessary on the level of children, families, and educators in order to digitally empower Romanian children.

Table 1. Digital competences of children aged 4 to $6(N=18)$ and 6 to $8(N=7)$

\begin{tabular}{lrrrrrrrr}
\hline Digital competences & 1 & 2 & 3 & 4 & 5 & 6 & 7 & 8 \\
\hline Children aged 4-6 & 18 & 16 & 14 & 13 & 11 & 16 & 6 & 2 \\
\hline Children aged 6-8 & 7 & 7 & 7 & 7 & 7 & 6 & 5 & 4 \\
\hline
\end{tabular}

Note: 1 - start a YouTube video; 2 - take a photo and watch it; 3 - make a video and watch it; 4 - open a game and play; 5 - download a game and play; 6 - draw using the S-Note application; 7 - set the sound; 8 - check the Wi-Fi signal

\section{Parents in "Digiland"}

Family is the key socialization environment of young children. Daily routines, parents' skills and attitudes towards digital technology play a major role in developing their children's knowledge, skills, and attitudes when it comes to information and communication technologies (ICTs) (Marsh et al., 2017). Parents' access to "Digiland" ranges from moral panic and strict control to a more relaxed stance and a laissez-faire digital parenting style. However, the typical parent in Central Romania would be somewhere in-between, with a touch of scepticism and nostalgia. "We did not grow up like this... we played outdoors, we played a lot. In the evening, when the stars came up, we went home. Now the playgrounds are empty... for them, everything is about the Internet, computers, and smartphones. They do not read a book. I miss so many things from their life" (37-year-old mother).

The term "family literacy" (Compton-Lilly-Rogers-Lewin, 2012: 33) describes the integrated character of the digital lifestyle embedded in home environments. Due to the newly introduced digital manuals in Romania, school children's parents are confronted with difficulties in assisting their learning. A focus-group discussion carried out with parents revealed their frustration and concern related to their own digital incompetence and the children's increased screen time.

Technology consumption in domestic spaces is a common practice and under research scrutiny from the nineties onwards (Silverstone-Hirsch, 1992; 
Plowman-McPake-Stephen, 2008; Fleer, 2014; Nikken-Jansz, 2014). Parents' reports of their children's digital practices and daily routines show that small children use tablets, watch TV in the morning and late in the afternoon, before and after kindergarten/school, more often when the weather is cold or rainy. Parents control their screen time and are more concerned with health issues than with cybersecurity or their children's access to inappropriate online content. There is also a strong belief among Romanian parents that their children are born digitally, savvy, and they do not to teach them: the little ones know it better. Not only that parents' concerns are rather unilateral and restricted mostly to health issues and screen time, but they are not really immersed in their kids' world of online playing. Their access to "Digiland" is on a rather narrow path despite their efforts to be part of their children's virtual playgrounds.

\section{Teachers in "Digiland"}

We interviewed a total of 17 teachers from four towns, a large city, and a village from Central Romania. Our research focused on the role played by digital technology in educators' personal and professional lives, the level of their digital literacy, and their development needs. We found striking differences not so much along age but rather along residence (urban versus rural) and the level of technological endowment of schools. We will compare and contrast two teachers' account of digital life, focusing on socio-demographic factors, and their attitudes towards developing their own digital competences.

Table 2. Two teachers in "Digiland"

\begin{tabular}{|c|c|c|}
\hline Criteria & Emma, 34 & Lidia, 46 \\
\hline $\begin{array}{l}\text { School size and } \\
\text { location }\end{array}$ & $\begin{array}{l}\text { Rural school in a village of } \\
1,900 \text { inhabitants, Central } \\
\text { Euroregion of Romania, } 175 \\
\text { students }\end{array}$ & $\begin{array}{l}\text { Elite Catholic school in } \\
\text { a small town of } 34,200 \\
\text { inhabitants, Central } \\
\text { Euroregion of Romania, } 1,000 \\
\text { students. }\end{array}$ \\
\hline Teaching experience & 15 years & 27 years \\
\hline Support from parents & Limited & Full \\
\hline Support from school & Limited & Full \\
\hline $\begin{array}{l}\text { A day at school: how } \\
\text { do you use digital } \\
\text { technologies for } \\
\text { teaching? }\end{array}$ & $\begin{array}{l}\text { I use technology for } \\
\text { conveying information, such } \\
\text { as showing pictures from the } \\
\text { Internet or sounds like bird } \\
\text { tweets or downloading songs. } \\
\text { Sometimes, we listen to fairy } \\
\text { tales. }\end{array}$ & $\begin{array}{l}\text { I arrive at school at } 7: 30 \text {, } \\
\text { I switch the interactive } \\
\text { whiteboard on, and I check if } \\
\text { the Wi-Fi works because if it } \\
\text { does not, a paper-based day } \\
\text { will follow. }\end{array}$ \\
\hline
\end{tabular}




\begin{tabular}{|c|c|c|}
\hline Criteria & Emma, 34 & Lidia, 46 \\
\hline $\begin{array}{l}\text { A day at school: how } \\
\text { do you use digital } \\
\text { technologies for } \\
\text { teaching? }\end{array}$ & $\begin{array}{l}\text { Or when I teach Romanian } \\
\text { language: there are audio } \\
\text { materials for developing } \\
\text { comprehension skills, and I } \\
\text { also bring materials already } \\
\text { downloaded, such as tests. } \\
\text { Unfortunately, I do not use } \\
\text { enough technology in my } \\
\text { classes because the school has } \\
\text { a poor infrastructure: we only } \\
\text { have a laptop, a projector, and } \\
\text { amplification devices. I use } \\
\text { technology mainly for audio } \\
\text { materials or when I have } \\
\text { group activities. }\end{array}$ & $\begin{array}{l}\text { If the Wi-Fi and everything } \\
\text { else works, I check the } \\
\text { children's tablets if they can } \\
\text { connect to the educational } \\
\text { cloud. I integrate all these } \\
\text { devices. If we have a language } \\
\text { class, we listen to the audio } \\
\text { material, then read the text } \\
\text { sent on tablets. For feedback } \\
\text { purposes, there is a .pdf } \\
\text { application built in the tablets } \\
\text { so that children can fill in the } \\
\text { blanks. Thus, communication } \\
\text { is bidirectional. I can capture } \\
\text { the evaluation moment and } \\
\text { send it instantly to the parent. }\end{array}$ \\
\hline
\end{tabular}

Both teachers are motivated to integrate digital technology in class, but the differences in institutional support and available resources are striking. This showcase epitomizes the gap between the rural and the urban Romania, between privileged and underprivileged children.

\section{Concluding Remarks}

Parents and educators are disconnected from young children's universe. Factors enabling adults' access to "Digiland" are multifold: infrastructural, psychological, social, and educational. Coping with the steep learning curve of digital literacy is a multiplayer game; our small-scale research has shown: domestic technological environment, institutional support of schools, and personal motivation are factors promoting or hindering ICT-related knowledge and skills. An upcoming largerscale quantitative research will bring more clarity to this issue.

Both parents and educators are striving to keep up with the Internet generation: a bumpy road marked by concerns and frustrations. Adults tend to overestimate young children's digital literacy and are rather sceptical when it comes to the revolutionary role technology plays in kids' lives. They are more concerned with health issues related to screen time than deeper and more complex threats such as cybersecurity or cyberbullying.

Schools might be enablers of digital literacy for both children and adults. More resources should be directed towards poor and disconnected regions, especially rural areas. Developing the digital literacy levels of educators might also help to create safer spaces for learning and playing for the benefit of young children. 


\section{References}

Arrow, A. W.-Finch, B. T. (2013). Multimedia Literacy Practices in Beginning Classrooms and at Home: the Differences in Practices and Beliefs. Literacy 27(3): 131-141.

Bakó, R. K. (2014). Children Online: a Participatory Visual Approach. Acta Universitatis Sapientiae, Communicatio 1: 75-86.

(2016). Digital Transition: Children in a Multimodal World. Acta Universitatis Sapientiae, Social Analysis 6(1): 145-154.

Blau, I.-Hameiri, M. (2016). Ubiquitous Mobile Educational Data Management by Teachers, Students and Parents: Does Technology Change School-Family Communication and Parental Involvement? Education and Information Technologies 21(3): 1-20.

Compton-Lilly, C.-Rogers, R.-Lewis, T. Y. (2012). Analyzing Epistemological Considerations Related to Diversity: an Integrative Critical Literature Review of Family Literacy Scholarship. Reading Research Quarterly 47(1): 33-60.

Fleer, M. (2014). The Demands and Motives Afforded through Digital Play in Early Childhood Activity Settings. Learning, Culture and Social Interaction 3: 202-209.

Helsper, E. J.-Reisdorf, B. C. (2016). The Emergence of a 'Digital Underclass' in Great Britain and Sweden: Changing Reasons for Digital Exclusion. New Media and Society (online first) 19(8): 1253-1270. DOI: 10.1177/1461444816634676.

Jones, L. M.-Mitchell, K. J. (2016). Defining and Measuring Youth Digital Citizenship. New Media and Society 18(9): 2063-2079.

Kahne, J.-Middaugh, E. (2012). Digital Media Shapes Youth Participation in Politics. Kappan 94(3): 52-56.

Marsh, J.-Mascheroni, G.-Carrington, V.-Árnadóttir, H.-Brito, R.-Dias, R.Kupiainen, R.-Trueltzsch-Wijnen, C. (2017). The Online and Offline Digital Literacy Practices of Young Children: a Review of the Literature. COST ACTION IS1410. www.digilitey.eu.

Marsh, J. (2011). Young Children's Literacy Practices in a Virtual World: Establishing an Online Interaction Order. Reading Research Quarterly 46(2): 101-118.

Mäkinen, M. (2006). Digital Empowerment as a Process for Enhancing Citizen Participation. E-Learning 3(3): 381-395.

Nikken, P.-Jansz, J. (2014). Developing Scales to Measure Parental Mediation of Young Children's Internet Use. Learning, Media and Technology 39(2): 250266.

Plowman, L.-McPake, J.-Stephen, C. (2008). Just Picking It Up? Young Children Learning with Technology at Home. Cambridge Journal of Education 38: 303-319. Silverstone, R.-Hirsch, E. (eds). (1992). Consuming Technologies: Media and Information in Domestic Spaces. London-New York: Routledge. 
Tókés, Gy. (2016). Visual Research to Study the Digital Literacy and Multimodal Practices of Romanian Pre-School Children. Acta Universitatis Sapientiae, Communicatio 3: 59-72.

Wellman, B.-Quan-Haase, A.-Boase, J.-Chen, W.-Hampton, K.-Díaz, I.-Myata, K. (2003). The Social Affordances of the Internet for Networked Individualism. Journal of Computer-Mediated Communication 8(3). DOI: 10.1111/j.10836101.2003.tb00216.x. 